\title{
Crude glycerine in growing and finishing pigs feeding
}

\section{Glicerina bruta na alimentação de suínos na fase de crescimento e terminação}

\author{
Paulo Levi de Oliveira Carvalho ${ }^{1 *}$; Ivan Moreira²; Cláudio Scapinello²; \\ Liliane Maria Piano ${ }^{1}$; Adriana Gomez Gallego ${ }^{1}$; Gabriel Moresco ${ }^{3}$
}

\begin{abstract}
Two experiments were carried out aiming to determine the nutritional value and to evaluate performance, carcass traits and economic feasibility of growing-finishing pigs fed on two types of crude glycerine (CG) which were made from vegetable oil (CGS), and mixed of animal fat + soybean oil (CGA). In Experiment I, a digestibility assay were carried out using 32 (24 test diet and 8 basal diet) cross breed pig $(45.08 \pm 4.11 \mathrm{~kg})$. The experimental unit consisted of one pig, with a total of four experimental units per diet. Glycerine levels used in the digestibility assay were 6,12 , and $18 \%$ of the basal diet (corn + soybean meal based). The values (as-fed-basis) of DE and ME ( $\mathrm{kcal} / \mathrm{kg}$ ) obtained were: CGS $=5,040$ and 4,481; CGA = 5,234 and 4,707, respectively. In the Experiment II, 63 pigs, were allotted in a completely randomized design in $2 \times 4$ factorial scheme, with two types of crude glycerine (CGS and CGA) and four inclusion levels $(3,6,9$, and $12 \%)$. Additionally, it was formulated a control diet containg no glycerine $(0 \%)$. There was no interaction $(\mathrm{P} \geq 0.05)$ among levels of $\mathrm{CG}$ and types of glycerine sources, and the regression analysis indicates no effects $(\mathrm{P} \geq 0.05)$ of crude glycerine inclusion on performance and carcass traits (backfat thickness and loin depth). The results suggest that it is feasible to use up to $12 \%$ of both crude glycerine (made from soybean oil and mixed) on growing-finishing pigs diet, without impairing performance and carcass traits, besides providing a reduction of about $11 \%$ on feeding cost.

Key words: Biodiesel, co-product, digestibility, glycerol
\end{abstract}

\section{Resumo}

Foram conduzidos dois experimentos com o objetivo de determinar o valor nutricional e avaliar o desempenho, característica de carcaça e viabilidade econômica de suínos em fase de crescimento e terminação alimentados com rações contendo dois tipos de glicerinas brutas: GBV - oriunda de óleo vegetal (soja) e GBM - mista, oriunda de gordura animal e óleo de soja. No Experimento I, foi conduzido um ensaio de digestibilidade com 32 (24 rações testes e 8 ração referência) suínos $(45,08$ $\pm 4,11 \mathrm{~kg}$ ) mestiços. A unidade experimental consistiu-se de um suíno, totalizando quatro unidades experimentais por ração. Os níveis de substituição da ração referência pela glicerina foram 6,12 e $18 \%$. Os valores de ED e EM (kcal/kg), na matéria natural, obtidos foram: GBV=5.040 e 4.481 e $\mathrm{GBM}=5.234$ e 4.707, respectivamente. No Experimento II, foram utilizados 63 suínos, distribuídos em delineamento inteiramente casualizados, em esquema fatorial $2 \times 4$, sendo dois tipos de glicerina bruta (GBV e GBM) e quatro níveis de inclusão (3, 6, 9 e 12\%). Adicionalmente, foi formulada uma ração testemunha, não contendo glicerina $(0 \%)$. Não houve interação $(\mathrm{P} \geq 0,05)$ entre os níveis de inclusão e o tipo da glicerina bruta. A análise de regressão indica que não houve efeito $(\mathrm{P} \geq 0,05)$ do nível de inclusão das glicerinas brutas sobre o desempenho e característica de carcaça (espessura de toucinho

\footnotetext{
1 Discente(s) de pós-graduação em Zootecnia da Universidade Estadual de Maringá, UEM, Av. Colombo, 5790, CEP: 87020-900, Maringá, PR.E-mail: paulolevi@yahoo.com.br; liliane_piano@hotmail.com; adritonyv@yahoo.es

2 Profs. do Dept ${ }^{\circ}$ de Zootecnia, UEM, Maringá, PR. E-mail: imoreira@uem.br; cscapinello@uem.br

3 Discente de Graduação de Zootecnia, UEM, Maringá, PR. E-mail:gabe_moresco@yahoo.com.br * Author for correspondence
} 
e profundidade de lombo). Os resultados de sugerem que é viável a utilização em até $12 \%$, de ambas as glicerinas brutas (de origem vegetal e mista), na alimentação de suínos na fase de crescimento e terminação, sem prejuízos no desempenho e característica de carcaça, além de propiciar a redução de cerca de $11 \%$ no custo da alimentação.

Palavras-chave: Biodiesel, coproduto, digestibilidade, glicerol

\section{Introduction}

Although the biodiesel production may not attend future demand projections, it is expected to increase even further the availability of crude glycerine. In 2011, 273,353 cubic meters of crude glycerine were produced in Brazil (ANP, 2013), which is an environmental and logistics problem for biodiesel production industries. However, in swine production, glycerine can be an alternative source of high potential energy in the diet replacing corn.

Glycerine can be sold without purification (natural glycerine), in crude form (high content of fatty acids), semipurified, better known as "Blonde" (low fatty acid content) and purified (95 to 99\% of glycerine). According to Rivaldi et al. (2008), despite the use of purified glycerine in cosmetics and food, its production involves the additional cost of purification which is too high. For this reason, crude glycerine has high levels of fatty acids, catalysts residues and a certain amount of methanol.

Since the 1990s, the use of glycerine as feedstuffs for pigs has been investigated in order to verify the effects of this co-product of biodiesel production on performance, carcass traits and meat quality of pigs. Studies from Mourot et al. (1993) and Mourot (2009) with the inclusion of up to $5 \%$ of crude glycerine in growing and finishing pigs feeding highlight the tendency to reduce the effect of the qualitative carcass traits, such as drip and cooking losses.

So, this study aims to evaluate the nutritional value and effects of the inclusion of two types of crude glycerine (vegetable and mixed) on performance, carcass traits and economic feasibility on growing and finishing pigs.

\section{Material and Methods}

The experiments were carried out at the Iguatemi Experimental Farm, belonging to the State University of Maringá (CCA / UEM).

Two crude glycerine (CG) were studied: $\underline{\mathrm{CGS}}$ made from vegetable oil (soybean); $\underline{\mathrm{CGA}}$ - mixed, made from about $80 \%$ of animal fat $+20 \%$ soybean oil. Both were obtained from Biopar biofuels industry, located in Rolândia - PR.

Two experiments were carried out, a digestibility assay (Experiment I) and a performance trial (Experiment II). In experiment I, 32 (24 test diet and 8 basal diet) crossbred barrows from commercial line with $45.08 \pm 4.11 \mathrm{~kg}$ of initial live weight. The animals were kept individually in metabolism cages similar to those described by Pekas (1968), in a room with controlled temperature. The control diet consisted of corn $(72.97 \%)$, soybean meal $(24.45 \%)$, common salt $(0.570 \%)$, limestone $(0.635 \%)$, dicalcium phosphate $(0.875 \%)$ and vitamin-mineral premix $(0.50 \%)$, it was formulated to meet the requirements indicated by Rostagno et al. (2005).

Four experimental units were used per treatment. Substitution levels of basal diet for glycerine were 6,12 and $18 \%$, resulting in six test diet.

Diets supply, feces and urine collection were performed according to protocol described by Sakomura and Rostagno (2007). In the collection period, the diet supply was calculated based on metabolic weight $\left(\mathrm{kg}^{0.75}\right)$ of each pig and on the average intake recorded in the pre-experimental period. Feeding was offered at $08 \mathrm{~h}$ and $15 \mathrm{~h}$, being $55 \%$ of the total in the morning and $45 \%$ in the afternoon. All diets were moistened with approximately $20 \%$ of water, aiming to avoid waste, reduce dustiness and improve feed acceptability by 
the animal. After each meal, water was provided at the feeder ( $3 \mathrm{~mL}$ of water/g of diet) to avoid excessive water consumption. The chemical composition of the diets and the feces were evaluated by the Laboratório de Nutrição Animal at Universidade Estadual de Maringá, in accordance with the methodologies described by Silva and Queiroz (2002).

The coefficient of dry matter digestibility, organic matter, gross energy and the metabolization coefficient of gross energy were calculated according to Matterson, Potter and Stutz (1965). The digestible (DE) and metabolizable energy (ME) values were estimated by regression analysis (ADEOLA; ILELEJI, 2009) of DE and ME intake (kcal / kg) associated of crude glycerine vs. crude glycerine intake. To evaluate differences between the digestibility of CGS and CGA, the data were subjected to variance analysis using the statistical package SAEG (UFV, 1997) according to the following statistical model: $Y i j=\mu+\mathrm{T} i+\mathrm{e} i j$ where: $\mathrm{Y} i j=$ digestibility coefficient of the treatment $\mathrm{i}$, of repetition $\mathrm{j} ; \mu=$ constant associated with all observations; $\mathrm{T} i=$ effect of inclusion level of food $i$, being $i=6 ; 12 ; 18 \%$; eij $=$ random error associated with each observation.

In experiment II, 63 crossbred pigs of commercial line were used, with initial average weight of 30.53 \pm 1.59 and final of $59.55 \pm 4.27 \mathrm{~kg}$ in the growing and with initial weight of $60.35 \pm 2.25$ and final of $89.91 \pm 5.23 \mathrm{~kg}$ in the finishing phase.

Treatments consisted of nine experimental diets with increasing levels of inclusion $(0,3,6$, 9 and $12 \%$ ) of two types of crude glycerine (CGS and CGA). The diets based on corn and soybean meal (Tables 1 and 2) were formulated to meet the recommended by Rostagno et al. (2005) for growing and finishing pigs.

For diet formulations, the chemical and energetic composition of crude glycerine (CGS and CGA) (Table 3) obtained in the digestibility trial was used. For other ingredients such as corn and soybean meal the values of crude protein, phosphorus and calcium were determined.

Pigs were allotted in a randomized complete block design with repetitions in time, in a factorial $2 \times 4$, two types of crude glycerine (CGS and CGA) and four levels of inclusion (3, 6, 9 and 12\%), with seven replicates and a pig for each experimental unit. Additionally, a control diet was formulated containing $0 \%$ of glycerine. At the end of the growing, the animals were assigned randomly into experimental units and treatments, avoiding staying in the same treatment.

Pigs were weighed at the beginning and at the end of the experiment and the total feed intake were computed, which was used to calculate the daily feed intake (DFI), daily weight gain (DWG) and feed:gain ratio $(F: G)$ of each experimental unit. At the end of the growing and finishing, the backfat thickness and loin depth were measured at the P2 position using the device Sono-Grader $\left(\operatorname{Renco}^{\circledR}\right)$.

Using the data of DWG and DFI, the economic analysis was made based on the equation proposed by Guidoni (1994):

$\mathrm{PMCG} \leq\left[\mathrm{PRP}\left(\right.\right.$ Gain $\left.\left._{\mathrm{i}}-\mathrm{Gain}_{0}\right)-\sum_{\mathrm{J} \neq \mathrm{L}=1}^{\mathrm{N}} P_{J}\left(\mathrm{C}_{\mathrm{ji}} * \mathrm{FI}_{\mathrm{i}}-\mathrm{C}_{\mathrm{j} 0} * \mathrm{FI}_{0}\right)\right] /\left(\mathrm{C}_{\mathrm{li}} * \mathrm{FI}_{\mathrm{i}}\right)$ 


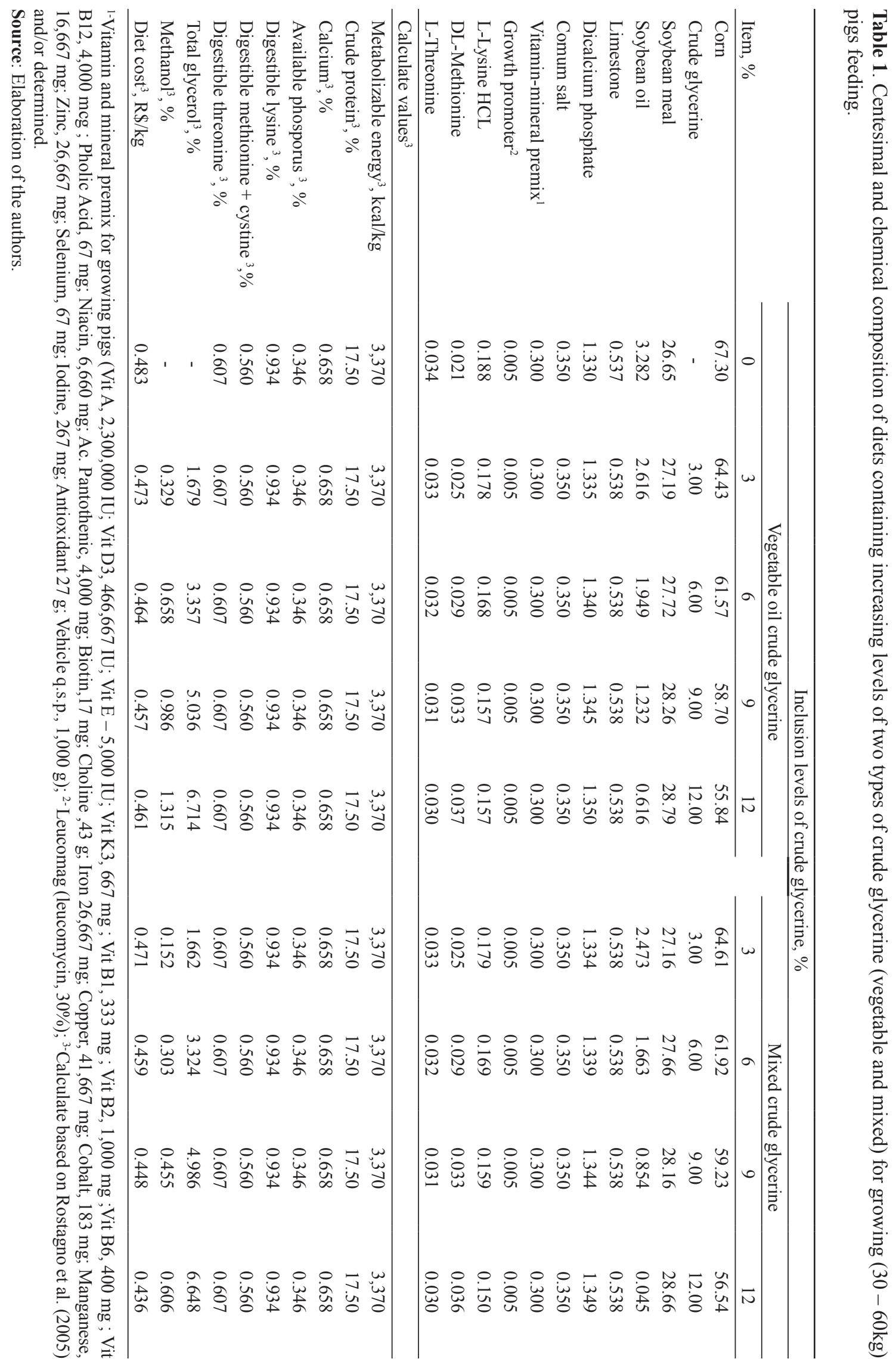


Table 2. Centesimal and chemical composition of diets containing increasing levels of two types of crude glycerine (vegetable and mixed) for fishing $(60-90 \mathrm{~kg})$ pigs feeding.

\begin{tabular}{|c|c|c|c|c|c|c|c|c|c|}
\hline \multirow[b]{3}{*}{ Item, $\%$} & \multicolumn{9}{|c|}{ Inclusion levels of crude glycerine, $\%$} \\
\hline & \multicolumn{5}{|c|}{ Vegetable oil crude glycerine } & \multicolumn{4}{|c|}{ Mixed crude glycerine } \\
\hline & 0 & 3 & 6 & 9 & 12 & 3 & 6 & 9 & 12 \\
\hline Corn & 76.95 & 74.57 & 71.51 & 69.13 & 65.95 & 74.74 & 71.90 & 69.03 & 66.72 \\
\hline Crude glycerine & - & 3.00 & 6.00 & 9.00 & 12.00 & 3.00 & 6.00 & 9.00 & 12.00 \\
\hline Soybean meal & 17.55 & 17.59 & 18.34 & 18.39 & 19.25 & 17.55 & 18.24 & 18.93 & 19.04 \\
\hline Soybean oil & 3.273 & 2.588 & 1.927 & 1.243 & 0.586 & 2.452 & 1.640 & 0.836 & 0.012 \\
\hline Limestone & 0.561 & 0.556 & 0.550 & 0.545 & 0.539 & 0.568 & 0.551 & 0.545 & 0.541 \\
\hline Dicalcium phosphate & 0.952 & 0.960 & 0.964 & 0.973 & 0.977 & 0.960 & 0.964 & 0.968 & 0.976 \\
\hline Comum salt & 0.350 & 0.350 & 0.350 & 0.350 & 0.350 & 0.350 & 0.350 & 0.350 & 0.350 \\
\hline Vitamin-mineral premix ${ }^{1}$ & 0.150 & 0.150 & 0.150 & 0.150 & 0.150 & 0.150 & 0.150 & 0.150 & 0.150 \\
\hline Growth promoter ${ }^{2}$ & 0.005 & 0.005 & 0.005 & 0.005 & 0.005 & 0.005 & 0.005 & 0.005 & 0.005 \\
\hline L-Lysine HCL & 0.181 & 0.185 & 0.168 & 0.172 & 0.152 & 0.186 & 0.171 & 0.155 & 0.157 \\
\hline DL-Methionine & 0.005 & 0.012 & 0.013 & 0.020 & 0.020 & 0.012 & 0.013 & 0.014 & 0.020 \\
\hline L-Threonine & 0.023 & 0.028 & 0.024 & 0.030 & 0.024 & 0.029 & 0.025 & 0.021 & 0.026 \\
\hline \multicolumn{10}{|l|}{ Calculate values $^{3}$} \\
\hline Metabolizable energy ${ }^{3}, \mathrm{kcal} / \mathrm{kg}$ & 3,400 & 3,400 & 3,400 & 3,400 & 3,400 & 3,400 & 3,400 & 3,400 & 3,400 \\
\hline Crude protein ${ }^{3}, \%$ & 14.56 & 14.56 & 14.56 & 14.56 & 14.56 & 14.56 & 14.56 & 14.56 & 14.56 \\
\hline Calcium $^{3}, \%$ & 0.511 & 0.511 & 0.511 & 0.511 & 0.511 & 0.511 & 0.511 & 0.511 & 0.511 \\
\hline Available phosporus ${ }^{3}, \%$ & 0.262 & 0.262 & 0.262 & 0.262 & 0.262 & 0.262 & 0.262 & 0.262 & 0.262 \\
\hline Digestible lysine $^{3}, \%$ & 0.716 & 0.716 & 0.716 & 0.716 & 0.716 & 0.716 & 0.716 & 0.716 & 0.716 \\
\hline Digestible methionine + cystine ${ }^{3}, \%$ & 0.444 & 0.444 & 0.444 & 0.444 & 0.444 & 0.444 & 0.444 & 0.444 & 0.444 \\
\hline Digestible threonine $^{3}, \%$ & 0.480 & 0.480 & 0.480 & 0.480 & 0.480 & 0.480 & 0.480 & 0.480 & 0.480 \\
\hline Total glycerol ${ }^{3}, \%$ & - & 1.679 & 3.357 & 5.036 & 6.714 & 1.662 & 3.324 & 4.986 & 6.648 \\
\hline Methanol $^{3}, \%$ & - & 0.329 & 0.658 & 0.986 & 1.315 & 0.152 & 0.303 & 0.455 & 0.606 \\
\hline Diet $\operatorname{cost}^{3}, \mathrm{R} \$ / \mathrm{kg}$ & 0.430 & 0.420 & 0.411 & 0.402 & 0.393 & 0.418 & 0.406 & 0.394 & 0.383 \\
\hline
\end{tabular}

1-Vitamin and mineral premix for fishing pigs (Vit A, 2,666,660 IU; Vit D3, 533,300 IU ; Vit E, 4,667 IU ; Vit K3, 1,200 mg ; Vit B1, $200 \mathrm{mg}$; Vit B2, 13.336 mg; Vit B6, $133 \mathrm{mg}$; Vit B12, 6,667 mcg; Pholic Acid, 34 mg; Niacin, 10,000 mg; Pantothenic, 666,666 mg; Biotin, 20 mg; Choline, 62 g; Iron, 40 mg; Copper, 86,805 mg; Cobalt, 334 mg; Manganese, 30,000 mg; Zinc, 46,666,0 mg; Selenium, 67 mg; Iodine, 400 mg; Antioxidant, 40 g; Vehicle q.s.p., 1,000 g); ${ }^{2-}$ Leucomag (Leucomycin, 30\%); ${ }^{3-C a l c u l a t e ~ b a s e d ~}$ on Rostagno et al. (2005) and/or determined.

Source: Elaboration of the authors.

Where: $\underline{\mathrm{PMCG}}=$ maximum price for crude glycerine (CGS and CGA) so that the diet in which it will be used reach the same economic efficiency as crude glycerine-free diet (zero level of inclusion); $\mathrm{PRP}=$ price per kilogram of pig; $\underline{\text { Gain }}_{\mathrm{i}}=$ average weight gain of pigs from treatment containing the $i$ level of crude glycerine $(\mathrm{CG})$; $\underline{\text { Gain }}_{\underline{0}}=$ average weight gain of pigs from treatment without $\mathrm{CG}$ (zero level of inclusion); $\underline{P}_{\mathrm{i}}=$ price of the remaining ingredients in each diet; $\underline{C}_{\mathrm{ii}}=$ percentage of the $\mathrm{j}$ ingredient in diet $\mathrm{i}$; $\underline{\text { FIi }}=$ Average feed intake for diet $\mathrm{i} ; \underline{\mathrm{C}}_{\mathrm{j} 0}=$ percentage of the $\mathrm{j}$ ingredient in the diet without $\mathrm{CG} ; \underline{\mathrm{FI} 0}=$ Average feed intake for diet without $\mathrm{CG} ; \underline{\mathrm{C}}_{\underline{\mathrm{i}}-\mathbf{}}=$ percentage of $\mathrm{CG}$ in the diet $\mathrm{i}$.

The input prices ( $\mathrm{R} \$$ ) were obtained in MaringáPR: 1.6 for swine $\mathrm{kg}$; 0.272 for corn; 0.629 for soybean meal; 1.98 for soybean oil; 0.16 for limestone; 1.12 for dicalcium phosphate; 0.34 for comum salt; 9.00 for lysine, 14.0 for methionine; 11.46 for threonine; 97.00 for the growth promoter and 0.29 for CGS and CGA.

In order to evaluate the performance data, the values were subjected to analysis of variance, adopting the following statistical model: $\mathrm{Y}_{i j l k}=\mathrm{m}+$ 
$\mathrm{B}_{i}+\mathrm{S}_{j+} \mathrm{N}_{k}+\mathrm{F}_{l}+N F_{k l}+\mathrm{e}_{i j k l}$, where $\mathrm{Y}_{i j k l}=$ observation of animal $l$, within the block i, inclusion level $k$ and crude Glycerine type $l ; \mathrm{m}=$ constant associated to all observations; $\mathrm{B} i=$ block effect, being $i=1,2,3$, 4,$5 ; \mathrm{S}_{\mathrm{j}}=$ effect of sex $\mathrm{j}(1=$ male, $2=$ female $) ; \mathrm{N} k$ $=$ effect of crude glycerine level, being $k=3,6,9$, $12 \% ; \mathrm{F} l=$ effect of the type of crude glycerine, being $l=\mathrm{CGS}$ and CGA; NFkl = interaction effect of the inclusion levels $k$ and the crude glycerine type $l$ and $\mathrm{e}_{i j k l}=$ random error associated with observation.

The degrees of freedom of the inclusion levels (CGS and CGA) were decomposed in orthogonal polynomials, to obtain the regression equations.

To compare the results of the control diet $(0 \%$ crude glycerine) at each level of inclusion of CGS and CGA, the Dunnett test was applied (SAMPAIO, 1998). Statistical analysis was performed using the statistical package SAEG. In the performance experiment, the initial weight of pigs was used as co-variable.

\section{Results and Discussion}

The physical, chemical and energetic composition of crude glycerine (CGS and CGA) (Table 3), are in agreement with the results quoted by Kerr et al. (2009) for the levels of glycerol (51.54\%), moisture $(4.99 \%)$, gross energy $(5,581 \mathrm{kcal} / \mathrm{kg})$, total fatty matter (24.28\%), methanol (14.99\%) and ash $(4.20 \%)$ in crude glycerine obtained from chicken fat, the values show that crude glycerine has a wide variation in its chemical composition.
The digestibility coefficients values, metabolism and digestible nutrients (Table 4) of crude glycerine (CGS and CGA) showed that both are excellent energy sources to feed pigs in the initial phase and with high utilization by animals. The presence of elevated levels of total fatty acids in CGS and CGA provides high energy content. A difference in chemical composition of crude glycerine affects its ME value, however, it is not clear whether different raw materials will also affect the value of ME.

The ratio of ME:DE (Table 4) for both glycerines (CGS and CGA) indicated that the co-products had high utilization by animals. In comparison, these values were reduced to those obtained by Lammers et al. (2008b) for pigs in the initial phase (92\%) fed with semipurified glycerine and to the values of corn and soybean oil (97\%) (ROSTAGNO et al., 2005). However, Kerr et al. (2009) using two crude glycerine derived from chicken fat, found a relationship ME: DE of $82-85 \%$. The authors note that this reduction, possibly, is due to the amount of fatty acids present in crude glycerine.

Mendoza et al. (2010) observed that the inclusion of up to $30 \%$ of purified glycerine may have been the limit for the glycerine metabolism and it could explain the increased excretion of energy in the urine and losses of glycerine metabolism. Doppenberg and Vand Der Aar (2007) studies, in pigs, confirm that there is a limitation in the activation of enzymes for glycerol use. High inclusion levels of glycerine in the diet provide low energy content, because the enzyme system (glycerol kinase) becomes saturated in the conversion of glycerol to glycerol3-phosphate, being this glycerol in excess, excreted in the urine. 
Table 3. Chemical and energetic composition of crude glycerines (as-fed basis).

\begin{tabular}{lcc}
\hline Nutrients & Vegetable oil crude glycerine & Mixed crude glycerine \\
\hline Moisture, \% & 2.54 & 5.45 \\
Total glycerol, \% & 55.95 & 55.45 \\
Crude protein, \% & 0.05 & 0.05 \\
Gross energy, kcal/kg & 5,247 & 5,242 \\
Total fatty acid, \% & 23.30 & 21.50 \\
MONG, \% ${ }^{1}$ & 37.43 & 34.48 \\
Methanol, \% & 10.96 & 5.05 \\
Ash, \% & 4.45 & 4.26 \\
Sodium chloride, \% & 3.52 & 3.01 \\
Calcium, ppm & 83.22 & 82.33 \\
Phosporus, ppm & 203.25 & 167.51 \\
Potassium, \% & 0.174 & 0.023 \\
Sodium, \% & 1.620 & 1.990 \\
Chloride, \% & 0.460 & 0.350 \\
Magnesium, ppm & 42.78 & 30.72 \\
Copper, ppm & 0.168 & 0.197 \\
Chrome, ppm & 0.241 & 0.177 \\
Iron, ppm & 22.37 & 26.51 \\
Zinc, ppm & 1.954 & 0.195 \\
Manganese, ppm & 0.442 & 0.853 \\
Aluminum, ppm & 52.82 & 33.48 \\
Cobalt, ppm & 0.532 & 0.475 \\
Molybdenum, ppm & 0.000 & 0.000 \\
Lead, ppm & 0.443 & 0.487 \\
pH & 8.75 & 8.55 \\
Density, kg/m ${ }^{3}$ & 1.090 & 1.110 \\
\hline
\end{tabular}

${ }^{1}$ MONG: organic matter non-glycerol. Defined as 100 - [glycerol content $(\%)+$ water content $(\%)+$ ash content (\%)].

Source: Elaboration of the authors.

Table 4. Apparent digestibility coefficients (DC), metabolization coefficient (MC) and digestible values of nutrients of two types of crude glycerine (vegetable and mixed) used on growing-finishing pigs feeding.

\begin{tabular}{lcc}
\hline Digestibility coefficients, \% & Vegetable oil crude glycerine & Mixed crude glycerine \\
\hline DC of dry matter & 92.07 & 94.98 \\
DC of organic matter & 91.85 & 95.58 \\
DC of fat & 99.43 & 100.14 \\
DC of gross energy & 96.06 & 99.85 \\
DM of gross energy & 85.38 & 89.95 \\
\hline Digestible nutrientes & As fed basis & As fed basis \\
\hline Dry matter,\% $\%$, & 89.73 & 89.80 \\
Organic matter, & 87.75 & 91.51 \\
Fat,\% & 23.17 & 21.53 \\
Digestible energy, kcal/kg & 5,040 & 5,234 \\
Metabolizable energy, $\mathrm{kcal} / \mathrm{kg}$ & 4,481 & 4,707 \\
ME:DE ration & 0.89 & 0.90 \\
\hline
\end{tabular}

Source: Elaboration of the authors. 
The slope of the linear relationship between metabolizable energy intake vs crude glycerines intake (CGS and CGA) (Figure 1) was estimated to obtain the ME of each type of crude glycerine, showing that the CGS and CGA have similar ME $(4,481$ and $4,707 \mathrm{kcal} / \mathrm{kg}$, respectively).
ME values in the crude glycerine (CGS and CGA) estimated by regression analysis (Figure 1) showed similar values to those obtained by Kerr et al. (2009) in experiments with the inclusion of different crude glycerine, from animal fat as raw material, and the values found were from 5,581 to $6,021 \mathrm{kcal} / \mathrm{kg}$ for GE, from 4,336 to $5,228 \mathrm{kcal} /$ $\mathrm{kg}$ for DE and from 4,446 to $5,206 \mathrm{kcal} / \mathrm{kg}$ for ME.

Figure 1. Equations of ME of two types of crude glycerine, obtained from regression of $\mathrm{ME}(\mathrm{kcal} / \mathrm{kg})$ intake associated of crude glycerine $v s$. crude glycerine intake $(\mathrm{kg})$, for 24 growing-finishing pigs, in five days.

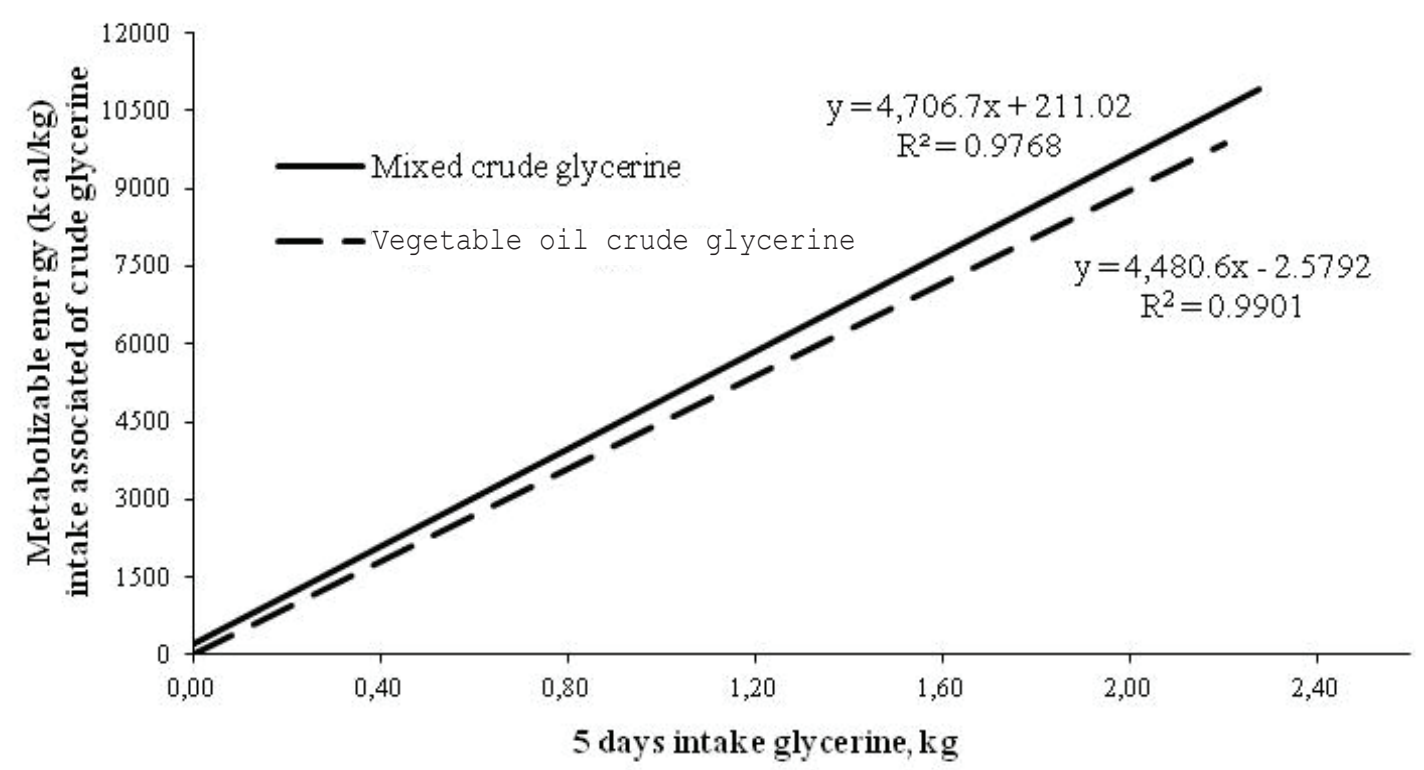

Source: Elaboration of the authors.

The metabolism of GE of glycerine can also be influenced by the presence of high levels of catalysts residues $\left(\mathrm{Na}^{+}\right.$and $\left.\mathrm{K}^{+}\right)$, used in the biodiesel production, which causes an increase in water consumption, consequently, in urine output. In the literature there are evidences that this production is influenced by the diets with high levels of glycerine. According to Lammers et al. (2008a), pigs fed with crude glycerine have more crude urinary energy by the higher volume of urine excreted, indicating that this co-product may have a diuretic effect in animals. However, the amount of these catalysts in the glycerine can be easily manipulated by the industry in the biodiesel production with recovery of the catalysts during the process.

For growing and finishing phases, there was no interaction $(\mathrm{P} \geq 0.05)$ between the levels of inclusion and the type of crude glycerine. Regression analysis indicates that there was no effect $(P \geq 0.05)$ of the inclusion level of crude glycerine for the DFI, DWG and FC variables (Table 5). Performance results also suggest that the increasing addition of glycerine in the diet had no effect on the feed palatability. According to Groesbeck et al. (2008), the crude glycerine has a sweet flavor, which can improve the palatability of diets and consequently feed intake. 
According to studies by Kijora and Kupsch (1996), the sweet and saline taste of glycerine showed higher feed intake in pigs (24.10 to 54.20 $\mathrm{kg}$ ) fed up to $10 \%$ glycerine with different levels of purification. Similar results were obtained by Mourot et al. (1994), Lammers et al. (2008a) and Schieck et al. (2010), evaluating the performance of growing-finishing pigs fed with 5 to $10 \%$ of inclusion of semipurified glycerine obtained from animal fat and vegetable oil. Mendoza et al. (2010), using purified glycerine, recommend adding up to $15 \%$ in of growing pigs feeding, without loss in performance.

Likewise, for Backfat thickness (BT-P2) and Loin depth (LD) variables, there was no interaction $(\mathrm{P} \geq 0.05)$ between the levels of inclusion and the type of crude glycerine. Regression analysis indicates that inclusion levels of crude glycerine did not affect $(P \geq 0.05)$ the variables studied (Table 5).

No effect on BT-P2 in growing pigs (50.9 to $105.2 \mathrm{~kg}$ ), fed with the inclusion of up to $16 \%$ of semipurified mixed glycerine was observed by Hansen et al. (2009). On the other hand, studies with inclusion of 5 to $10 \%$ of glycerine observed reduction in backfat thickness in pigs (DUTTLINGER et al., 2012; HANCZAKOWSKA et al., 2010).
Applying the prices to the equations according to Guidoni (1994), it was obtained the maximum prices (R\$) of CGS and CGA so that the experimental diets have the same economic efficiency of the diet without addition of glycerine. Thus, the maximum prices of $0.561 ; 0.488 ; 0.741$ and 0.479 were obtained for CGS and $0.797 ; 0.516 ; 0.418 ; 0.718$ for CGA in the growing phase, and $0.916 ; 0.432 ; 0.375$; 0.664 were obtained for CGS and $0.240 ; 0.411$; 0.533 and 0.678 for CGA in the finishing phase, referring to the inclusion levels of 3, 6, 9 and $12 \%$. It was observed that the glycerine is economically viable for all inclusion levels.

The economic analysis indicates that the use of up to $12 \%$ of CGS and CGA in isoenergetic diets can reduce the feeding costs of pigs $(30-90 \mathrm{~kg})$ by up to $11 \%$ (Table 2 and 3: $0.383 / 0.430=0.89$ ), compared to the diet without glycerine $(0 \%)$. 


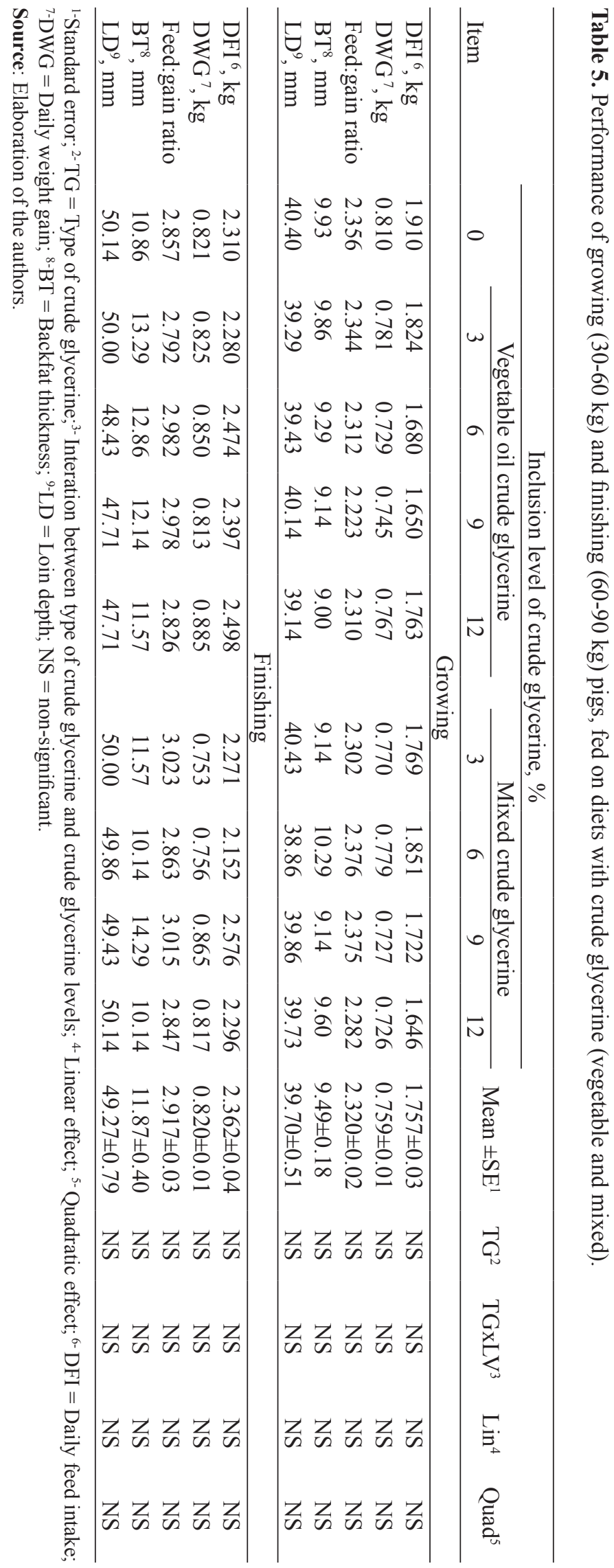




\section{Conclusions}

Values of metabolizable energy, as-fed basis, for vegetable oil and mixed glycerine are 4,481 and $4,707 \mathrm{kcal} / \mathrm{kg}$, respectively. There by providing a highly available energy source for growing e finishing pigs.

The results suggest that for diets of pigs $(30-90$ $\mathrm{kg}$ ) it is possible to use up to $12 \%$ of either types of crude glycerine, without interfering on performance and carcass in growing and finishing pigs. In addition, the inclusion of crude glycerine can provide up to $11 \%$ reduction in feed cost. However, the economic feasibility of its use will depend on the price relationship between the ingredients, especially corn and soybean oil (or other energy source).

\section{Acknowledgements}

BIOPAR, for providing the glycerines and to CAPES and CNPq, for the scholarship and research grant.

\section{References}

ADEOLA, O.; ILELEJI, K. Comparison of two diet types in the determination of metabolizable energy content of corn distillers dried grains with soluble for broiler chickens by regression method. Poultry Science, Champaign, v. 88, p. 579-585, 2009.

AGÊNCIA NACIONAL DE PETRÓLEO - ANP. Anuário Estatístico Brasileiro do Petróleo, Gás Natural e Biocombustíveis. Biodiesel. 2013. Disponível em: $<$ http://www.anp.gov.br>. Acesso em: 22 mar. 2013.

DOPPENBERG, J.; VAN DER AAR, P. The nutritional value of biodiesel by-products (Part2: Glycerine). A high energy liquid product, glycerine offers livestock producers the option of a cost effective alternative feed ingredient. Feed Busines Asia, p. 42- 43, 2007.

DUTTLINGER, A. W.; BENZ, J. M.; HOUSER, T. A. Effects of increasing crude glycerol and dried distillers grains with solubles on growth performance, carcass characteristics, and carcass fat quality of finishing. Journal of Animal Science, Champaign, v. 90, n. 3, p. 840-852-2236, 2012.
GROESBECK, C.N.; MCKINNEY, L. J.; DEROUCHEY, J. M.; TOKACH, M. D.; GOODBAND, R. D.; DRITZ, S. S.; NELSSEN, J. L.; DUTTLIGNER, A. W.; FAHRENHOLZ, A. C.; BEHNKE, K. C. Effect of crude glycerol on pellet mill production and nursery pig growth performance. Journal of Animal Science, Champaign, v. 86, n. 9, p. 2228-2236, 2008.

GUIDONI, A. L. Alternativas para comparar tratamentos envolvendo o desempenho nutricional animal. 1994. Tese (Doutorado em Agronomia) - Escola Superior de Agricultura Luiz de Queiroz, Piracicaba.

HANCZAKOWSKA, E.; WEGLARZY, K.; SZYMCZYK, B.; HANCZAKOWSK, P. Effect of adding crude or refined glycerol to pig diets on fattening performance, nutrient digestibility and carcass evaluation, Annals Animal Science, Krakow, v. 10, n. 1, p. $67-73,2010$.

HANSEN, C. F.; HERNANDEZ, A.; MULLAN, B. P.; MOORE, K.; TREZONA-MURRAY, M.; KING, R. H.; PLUSKE, J. R. A chemical analysis of samples of crude glycerol from the production of biodiesel in Australia, and the effects of feeding crude glycerol to growingfinishing pigs on performance, plasma metabolites and meat quality at slaughter. Animal Production Science, New Haven:Connecticut, v. 49, n. 2, p. 154-161, 2009.

KERR, B. J.; WEBER, T. E.; DOZIER, W. A.; KIDD, M. $T$. Digestible and metabolizable energy content of crude glycerin originating from different sources in nursery pigs. Journal of Animal Science, Champaign, v. 87, n. 12, p. 4042-4049, 2009.

KIJORA, C.; KUPSCH, R. D. Evaluation of technical glycerols from "Biodiesel" production as a feed component in fattening of pigs. Lipid-Fett, Weinheim, v. 98, n. 7, p. 240-245, 1996.

LAMMERS, P. J.; KERR, B. J.; WEBER, T. E.; BREGENDAHL, K.; LONERGAN, S. M.; PRUSA, K. J.; AHN, D. U.; STOFFREGEN, W. C.; DOZIER, W. A.; HONEYMAN, M. S. Growth performance, carcass characteristics, meat quality, and tissuehistology of growing pigs fed crude glycerin-supplemented diets. Journal of Animal Science, Champaign, v. 86, n. 11, p. 2962-2970, 2008a.

LAMMERS, P. J.; KERR, B. J.; WEBER, T. E.; DOZIER, W. A.; KIDD, M. T.; BREGENDAHL, K.; HONEYMAN, M. S. Digestible and metabolizable energy of crude glycerol for growing pigs. Journal of Animal Science, Champaign, v. 86, n. 3, p. 602-608, 2008b. 
MATTERSON, L. D.; POTTER, L. M.; STUTZ, M. W. The metabolizable energy of feed ingredients for chickens. storrs, connecticut university of connecticut, agricultural experiment station. Research Report, New Haven:Connecticut, v. 7, n. 1, p. 11-14, 1965.

MENDOZA, O. F.; ELLIS, M.; MCKEITH, F. K.; GAINES, A. M. Metabolizable energy content of refined glycerin and its effects on growth performance, and carcass and pork quality characteristics of finishing pigs. Journal of Animal Science, Champaign, v. 88, n. 12, p. 3887-3895, 2010.

MOUROT, J. Utilisation du glycérol en alimentation porcine. Inra Productions Animales, René Baumont, v. 22, n. 5, p. 409-414, 2009.

MOUROT, J.; AUMAITRE, A.; MOUNIER, A.; PEINIAU, P.; FRANÇOIS, A. C.; PEYRONNET, C.; JAMET, J. P. Effect du glycerol alimentaire sur les performances de croissance et la qualité de la viande chez le porc Large White. Journées Recherche Porcine en France, Paris, v. 25, n. 3, p. 29-35, 1993.

MOUROT, J.; AUMAITRE, A.; MOUNIER, A.; PEINIAU, P.; FRANÇOIS, A. C. Nutritional and physiological effects of dietary glycerol in the growing pig. Consequences on fatty tissues and post morten muscular parameters. Livestock Production Science, Amsterdam, v. 38, n. 3, p. 237-244, 1994.

PEKAS, J. C. Versatile swine laboratory apparatus for physiologic and metabolic studies. Journal Animal Science, Champaign, v. 27, n. 5. p. 1303-1309, 1968.
RIVALDI, J. D.; SARROUH, B. F.; FIORILO, R.; SILVA, S. S. Glicerol de biodiesel: estratégias biotecnológicas para o aproveitamento do glicerol gerado da produção de biodiesel. Revista Biotecnologia, Brasília, v. 10, n. 37, p. 44-51, 2008.

ROSTAGNO, H. S.; ALBINO, L. F. T.; DONZELE, J. L.; GOMES, P. C.; OLIVEIRA, R. F.; LOPES, D. C.; FERREIRA, A. S.; BARRETO, S. L. T.; EUCLIDES, R. F. Tabelas brasileiras para aves e suínos: composição de alimentos e exigências nutricionais. 2. ed. Viçosa: UFV, 2005. $186 \mathrm{p}$.

SAKOMURA, N. K.; ROSTAGNO, H. S. Métodos de pesquisa em nutrição de monogástricos. Jaboticabal: Funep, 2007. 283 p.

SAMPAIO, I. B. M. Estatística aplicada a experimentação animal. Belo Horizonte: Universidade Federal de Minas Gerais, 1998. 221 p.

SCHIECK, S. J.; SHURSON, G. C.; KERR, B. J.; JOHNSTON, L. J. Evaluation of glycerol, a biodiesel coproduct, in grow-finish pig diets to support growth and pork quality. Journal of Animal Science, Champaign, v. 88, n. 12, p. 3927-3935, 2010.

SILVA, D. J.; QUEIROZ, A. C. Análise de alimentos: métodos químicos e biológicos. 3. ed. Viçosa: Universidade Federal de Viçosa, 2002. 235 p.

UNIVERSIDADE FEDERAL DE VIÇOSA - UFV. SAEG - Sistema de análises estatísticas e genéticas. Versão 7.1. Viçosa: MG, 1997. 150 p. (Manual do usuário). 